\title{
Implementation of State Regulation of Small Enterprises in the Modern Economy
}

\author{
Bagautdinova N.G., Doctor of Economics, Professor \\ Malakhov V.P., Associate Professor, Ph.D. \\ Vardanyan E.A., Ph.D. \\ Shakhnina I.Z., Associate Professor, Ph.D.
}

Doi:10.5901/mjss.2014.v5n18p11

\begin{abstract}
The article analyses the dynamics of the development of small and medium-sized businesses, micro-enterprises and individual entrepreneurs in the whole country and by federal districts. Analyzed the legal and organizational basis of entrepreneurial activity. Designated areas of business regulation that developed measures aimed at promoting entrepreneurship in the country. Matrix of selection of preferred instruments and target figures of local state regulation of small business that take into account peculiarities of small enterprises of different types, is formed. In conclusion priority sequence of actions of providing efficient approach for state regulation of small business is composed.
\end{abstract}

Keywords: non-scalable business, small entrepreneurship, scalable business, small business, regulation .

\section{Introduction}

History of small business development in the Russian Federation of the period of structural reforms which started in the 90s of the XIX century, shows that significance of the role of this economic sector was traditionally admitted by representatives of alternative economic schools, political movements and leading elites. It was fixed in normative legal acts of the Russian state which traditionally included federal and regional laws, special programs aimed at small business development, etc. The fact that development of the legal base of entrepreneurship of modern Russian economy started from the laws defining the status of cooperatives and individual businessmen, which became the starting point of legitimation of market relations, is rather significant. However, the research study shows that many statements of program documents have declarative character as far as they do not allow to form effective system of measures of state influence that take into account peculiarities and potential of this business sector [1]. However, pathway of small business development in modern Russia is of steady character, which is reflected in its indices. According to the data of National Institute for Systemic Studies of Entrepreneurial Problems, by 2013 in the Russian Federation 1 997,0 thousand of small enterprises were registered (including 1759,0 thousands of microenterprises), which is higher for на 8,7\% than in 2012. At that number of small enterprises per 100000 citizens was 1395,9 which exceeds the number of 2012 for 110,5 enterprises. Number of small enterprises per 100000 citizens for 2012 fell in 14 regions. At the same time overall volume gross revenues of small enterprises in the Russian Federation for 2012 was 23 465,9 bln. rbs which is higher than the index of 2011 for only $3,8 \%$ (with the account of the index of consumer price index the gross revenues of small enterprises reduced for 2,4\%) [2]. It says about significant bottlenecks for further small business development in the Russian Federation, among which the most significant are the following: inconsistency of some norms of tax legislation, absence of necessary amount of current assets, low consumer demand of population, credit insecurity and high rent, insufficient personnel qualification and low legal security of activity, high transaction expenses of entry into economic sector, etc. [3, 4]. These contradictions are reflected in contradictory interests of society, business and state, which prevents implementation of the modern model of social contract [5].

\section{Methodology: Structuring of Types of Small Business}

Performance assurance of activity of local system of state regulation of small business in the frames of selection of preferred приоритетной меры воздействия, соответствующей особенностям развития малого предприятия [6,7], presupposes necessity of classification of the types of small business according to criteria of potential scalability (scalable and non-scalable business) and preferred direction of exit of business entity from the market (sale of business production business, transformation into public company, inheritance of business). Comparison of above-mentioned 
parameters allows to mark the following types of small enterprises:

1) scalable serial business entity: formation of small business enterprise of this type presupposes necessity to use innovation based on invention, or know-how or improving innovation, the use of which creates business capability to duplicate ideas in the frames of several local markets, as well as commitment of a businessman to company development with aim of its further acquisition by market players [8, 9];

2) non-scalable serial business entity: formation of small business enterprise of this type presupposes the use of improving innovation, property right for which is fixed for a businessman in legitimate for the national socialeconomic system form of intellectual property, development of which presupposes acquisition by large enterprise of the area of economic activity, in the frames of which the small business enterprises operates;

3) scalable business entity with potential of transformation into public company: formation of small business of this type should be based on basic or improving innovation, property right for which is confirmed by intellectual property item of businessman, the use of which allows to provide duplication of business format on different local markets in the process of small business development;

4) non-scalable business entity with potential of transformation into public company: formation of small business enterprise of this type is based on implementation of business idea on foundation of improving, basic or pseudo innovation, the use of which presupposes sales of products of small enterprise on different local markets in order to provide stable basis of development after transformation into public company;

5) scalable inherited business entity: small business enterprise of this type can be based on implementation of innovation of any type with the use of different kinds of sources of development ideas, with the aim of a businessman to provide duplication of business idea on different local markets as the peculiarity of it;

6) non-scalable inherited business entity: formation of business unit of this type presupposes possibility to create small business in the format of forced, as well as of directed at the use of possibility business, which uses innovation and source of the idea of development of different type, the aim of which is to maintain standard of well-being of a businessman and his family, as its basis.

Preferred format of instruments of state regulation of development of small business enterprise on the local level will be determined by the type of small business which is caused by necessity of selection of instruments which correspond to the small business structure formed in the frames of local entity to maximum extent.

\section{Choice of Priority Method of State Regulation of Small Business Development and Business Appraisal}

Choice of the method of local state regulation of small business development in conditions of modern Russian economy is determined, as the analysis carried out in the thesis work showed, first of all, by type of regulated small business enterprises [10], as well as by typological peculiarities of state regulation of this sphere which precondition the choice of the aim of state regulation of small business [11] on the local level (table 1).

Table 1: Matrix of choice of preferred instruments and aims of local state regulation of small business

\begin{tabular}{|c|c|c|c|c|}
\hline № & $\begin{array}{c}\text { Type of controlled } \\
\text { entity-small enterprise }\end{array}$ & Methods of direct control & Methods of indirect control & Aim of regulation \\
\hline 1 & 2 & 3 & 4 & 5 \\
\hline 1 & $\begin{array}{l}\text { Scalable serial business } \\
\text { structure }\end{array}$ & $\begin{array}{l}\text { 1. Simplification of procedure of } \\
\text { registration of intellectual property } \\
\text { right of business entity } \\
\text { 2. Change of tax regulations in the } \\
\text { process of development of small } \\
\text { enterprise }\end{array}$ & $\begin{array}{l}\text { 1. Simplification of procedures of } \\
\text { administration of functioning and } \\
\text { development of small business } \\
\text { 2. Revitalization of enforcement } \\
\text { institutions in a part of regulation of } \\
\text { intellectual property use }\end{array}$ & $\begin{array}{l}\text { Business growth on the } \\
\text { basis of inventions and } \\
\text { know-how }\end{array}$ \\
\hline 2 & $\begin{array}{l}\text { Non-scalable serial } \\
\text { business structure }\end{array}$ & $\begin{array}{l}\text { 1. Reduction of total taxation } \\
\text { burden at commercialization of } \\
\text { inventions } \\
\text { 2. Subsidizing of commercialization } \\
\text { of inventions }\end{array}$ & $\begin{array}{l}\text { 1. Simplification of accounting and } \\
\text { reporting procedures of activity of } \\
\text { business entity } \\
\text { 2. Monitoring of execution of } \\
\text { informal legal contracts connected } \\
\text { with development of business } \\
\text { organization }\end{array}$ & $\begin{array}{l}\text { Business growth on the } \\
\text { basis of commercialization } \\
\text { and inventions }\end{array}$ \\
\hline 3 & $\begin{array}{l}\text { Scalable business } \\
\text { structure } \\
\text { with potential of }\end{array}$ & $\begin{array}{l}\text { 1. Subsidizing of costs of business } \\
\text { entity for transformation into public } \\
\text { company }\end{array}$ & $\begin{array}{l}\text { 1. Creation and support of venture } \\
\text { investment funds and other forms of } \\
\text { organization of venture capital }\end{array}$ & $\begin{array}{l}\text { Business growth on the } \\
\text { basis of basic innovations } \\
\text { registered in the form of }\end{array}$ \\
\hline
\end{tabular}




\begin{tabular}{|c|c|c|c|c|}
\hline & $\begin{array}{l}\text { transformation into public } \\
\text { company }\end{array}$ & $\begin{array}{l}\text { 2. Formation of zones with special } \\
\text { tax regulations for small business } \\
\text { enterprises }\end{array}$ & $\begin{array}{l}\text { 2. Simplification of processes of } \\
\text { administration in some business } \\
\text { entities which are part of scalable } \\
\text { business }\end{array}$ & items of intellectual property \\
\hline 4 & $\begin{array}{l}\text { Non-scalable business } \\
\text { structure with potential of } \\
\text { transformation into public } \\
\text { company }\end{array}$ & $\begin{array}{l}\text { 1. Registration of small enterprises } \\
\text { in zones with special tax regulations } \\
\text { 2. Simplification of procedure of } \\
\text { registration of intellectual property } \\
\text { right }\end{array}$ & $\begin{array}{l}\text { 1. Simplification of processes of } \\
\text { administration of transformation into } \\
\text { public company } \\
\text { 2. Creation and support of venture } \\
\text { investment funds and other forms of } \\
\text { organization of venture capital }\end{array}$ & $\begin{array}{l}\text { Business growth on the } \\
\text { basis of improving } \\
\text { innovations registered in the } \\
\text { form of items of intellectual } \\
\text { property }\end{array}$ \\
\hline 5 & $\begin{array}{l}\text { Scalable inherited } \\
\text { business structure }\end{array}$ & $\begin{array}{l}\text { 1. Subsidizing of costs for } \\
\text { duplication of business idea on } \\
\text { markets out of the deployment } \\
\text { territory } \\
\text { 2. Government procurement for } \\
\text { work, production, services of small } \\
\text { enterprise }\end{array}$ & $\begin{array}{l}\text { 1. Reduction of entry administrative } \\
\text { barriers on business expansion in } \\
\text { scaling format } \\
\text { 2. Simplification of procedures of } \\
\text { registration of property right, } \\
\text { network connection }\end{array}$ & $\begin{array}{l}\text { Business growth on the } \\
\text { basis of duplicated } \\
\text { innovations and } \\
\text { development }\end{array}$ \\
\hline 6 & $\begin{array}{l}\text { Non-scalable inherited } \\
\text { business structure }\end{array}$ & $\begin{array}{l}\text { 1. Subsidizing of self-employment } \\
\text { and/or family business } \\
\text { 2. Government procurement for } \\
\text { services, production, work of small } \\
\text { enterprise }\end{array}$ & $\begin{array}{l}\text { 1. Simplification of accounting and } \\
\text { reporting procedures } \\
\text { 2. Reduction of quantity of planned } \\
\text { and unplanned inspections for one } \\
\text { business entity }\end{array}$ & $\begin{array}{l}\text { Formation of steady } \\
\text { platform of business growth }\end{array}$ \\
\hline
\end{tabular}

Efficient local regulation of development of small enterprises presupposes necessity to use different instruments of administration, the whole complex of which is determined by the type of controlled business and aim of state regulation.

Forecasting of development of small business enterprises in the frames of administratively localized economic space as holistic system presupposes necessity of assessing private tendencies of development of small business entities, as well as business development trend with account of the structure of small business. Formalization of such approach with account of necessity of assessment of dynamics of development of revealed in the frames of thesis work six main types of small business enterprises can be presented in the following way:

(1) $U_{\text {Mcnc }}=a_{1}+b_{1} B_{2 p n}+c_{1} B_{2 p k}$

(2) Инсnс $_{\text {Hon }}=a_{2}+b_{2} B_{\text {грп }}+c_{2} B_{\text {грк }}$

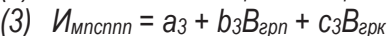

(4) $h_{\text {мncnnn }}=a_{4}+b_{4} B_{2 p n}+c_{4} B_{2 p k}$

(5) И $_{\text {мнnс }}=a_{5}+b_{5} B_{2 p n}+c_{5} B_{2 p k}$

(6) $И_{\text {ннпс }}=a_{6}+b_{6} B_{\text {грп }}+c_{6} B_{\text {грк }}$

where Имспс (нспс, мпсппп, нпсппп, мнпс, ннпс) - development indicators of accordingly scalable and non-scalable series business entity, scalable and non-scalable business entity with potential of transformation into public company, scalable and non-scalable inherited business entity, UM (unit of measure);

a $1-6$ - the invariable constant of equation of linear programming of development of accordingly scalable and nonscalable series business entity, scalable and non-scalable business entity with potential of transformation into public company, scalable and non-scalable inherited business entity which characterizes initial condition of an average business entity of this type,UM;

$b_{1-6}$ - the invariable constant of equation of linear programming of development of accordingly scalable and nonscalable series business entity, scalable and non-scalable business entity with potential of transformation into public company, scalable and non-scalable inherited business entity which characterizes initial impact of measures of direct state support of small business of this type, UM;

$\mathrm{C}_{1-6}$ - the invariable constant of equation of linear programming of development of accordingly scalable and nonscalable series business entity, scalable and non-scalable business entity with potential of transformation into public company, scalable and non-scalable inherited business entity which characterizes initial impact of measures of indirect state support of small business of this type;

$B_{\text {грп (грк) }}$ - the level of impact of measures of accordingly direct and indirect state support for development of small business enterprises in the frames of administratively localized economic space, UM.

Forecasting of the integral indicator of small business development in the frames of administratively localized economic space is implemented by calculation of weighted average by the level of significance of small business of every type (determined by share of small business of this type in the structure of small business of locally controlled space) of 
private indicators of progressive dynamics of small business enterprises of different types.

\section{Conclusion and Recommendations}

Systematization of the research results of restrictions of small business development in the Russian federation shows that business community thinks that inefficient state policy in the sphere of regulation of activity of business community, restricted access for financial resources and high level of polarization of this access in terms of business types of, lack of special education in business sphere, cultural and social restrictions of development of business in the society, availability of physical infrastructure and high level of polarization of the Russian economic space by the factor of the level of development of physical infrastructure are the key development restrictions. Removal of the above-mentioned barriers should be implemented by sequential replacement of methods of direct local state control of small business by indirect methods aimed at improvement of the effectiveness of institutional environment; it presupposes implementation of the following algorithm:

1. Assessment of current configuration of local regulation of small business. On this stage instruments of direct and indirect control in the frames of local system of regulation of small business development are determined, and performance evaluation of efficiency and effectiveness of this complex of instruments is made.

2. Determination of current structure of small business in the frames of administratively localized economic space. On this stage types and structure of small business enterprises functioning in the frames of administratively localized economic space, are determined.

3. Determination of key in the frames of administratively localized economic space restrictions of small business development. On this stage the list of the most significant restrictions of development of small business enterprises in the frames of administratively localized economic space is made, and ranking of their significance from the viewpoint of businessmen is implemented; it allows to determine preferred subjects of state regulation of environment of business development.

4. Determination of preferred methods of local state regulation of small business. Structure of preferred state regulating impact on processes of small business development in the frames of administratively localized economic space, which is based on the formed on the second stage assessment of current structure of small business, is formed on this stage.

5. Formation of set of measures of local state regulation of small business. On this stage the revealed on the third stage key restrictions of small business development and determined on the fourth stage preferred methods of state regulation, the comparison of which allows to adjust the preferred set of methods with account of the most significant restrictions of positive progressive dynamics of business, are compared.

6. Formation of the road map of local state regulation of small business. In the frames of this stage the list formed on the fifth stage is transformed into sequence of specific measures of state regulation, gradual reduction of share of measure of direct regulation with transition to methods of indirect small business regulation in mid-term perspective is the peculiarity of which.

In the process of implementation of the suggested algorithm formation of executive mechanisms which allow to provide the platform of steady development of small enterprises in the frames of administratively localized economic space on the basis of effective organizational procedures, will be ensured.

\section{References}

Averyanov B.A., Bagautdinova N.G., Sarkin A.V. Estimation of Manufacturing Enterprise Development Risks in Process of Operational Activity. World Applied Sciences Journal \#27, 2013

Dynamics of SME development in the regions of Russia in 2012. www.nisse.ru.

Bagautdinova N.G., Eshugova S.K., Saipullaev U., Karasik E.A. Methods of Technology Commercialization in Projects of the agrofood System (AFS) Development. World Applied Sciences Journal \#27, 2013

Sarkin A.V., Bagautdinova N.G., Averyanov B.A. Formation and Implementation of Comprehensive Science-Intensive Informational System of an Enterprise. World Applied Sciences Journal \#27, 2013.

Golodner A. Antitrust, innovation entrepreneurship and small business. Small Business Economics, Vol. 16, No. 1, Special Issue: The Invisible Part of the Iceberg: Research Issues in Industrial Organization and Small Business (Feb., 2001), pp. 31-35

Nystrom K. The institutions of economic freedom and entrepreneurship: evidence from panel data. Public Choice, Vol. 136, No. 3/4, Sep., 2008, pp. 269-282.

Naude W. Entrepreneurship, developing countries and developing economies: new approaches and insights. Small Business Economics, Vol. 34, No. 1, Special Issue Jan., 2010, pp. 1-12 
Lerner J. The boulevard of broken dreams: innovation policy and entrepreneurship. Innovation Policy and the Economy, Vol. 13, No. 1, Jan. 2013, pp. 61-82.

Stel v. A., Storey D., Thurik R. The effect of regulation of nascent and young entrepreneurship. Small Business Economics, Vol. 28 , No. 2/3, March 2007, pp. 171-186

Storey, D., Johnson, S. Job Generation and Labour Market Change, Macmillan, London, 1987. p. 126.

Acs Z., Szerb L. Entrepreneurship, economic growth and public policy. Small Business Economics, Vol. 28, No. 2/3, March, 2007, pp. 109-122

Isaeva, T.N., Safiullin, L.N., Bagautdinova, N.G., Shaidullin, R.N. Aspects of a multi-level study of competitive performance of objects and subjects of economic management // World Applied Sciences Journal, 27(13), 2013, 116-119.

Gainova R.A., Shaidullin R.N., Safiullin L.N. and Maratkanova E.M. Infrastructural Component in Maintenance of Competitiveness of Region// World Applied Sciences Journal, 27(13), 2013, pp. 97-101.

Safiullin M.R., Samigullin I.G. and Safiullin L.N. Model of Management of Competitiveness of a Machine-building Complex// World Applied Sciences Journal, 27(13), 2013, pp. 212-216.

Ulesov D.V., Shigabieva A.M., Maratkanova E.M. and Shaidullin R.N. Information Infrastructure of Small Business Development// World Applied Sciences Journal, 27(13), 2013, pp. 193-196.

Shaidullin R.N., Ulesov D.V., Shigabieva A.M. and Safiullin L.N. Innovative Infrastructure in Post-Industrial Society// World Applied Sciences Journal, 27(13), 2013, pp. 180-183.

Ulesov D.V., Murtazina G., Safiullin L.N. and Saipullaev U.A. Special Aspects of Development of Business in the Knowledge-Based Economy //World Applied Sciences Journal, 27(13), 2013, pp. 189-192.

Safiullin, M.R., Elstin, L.A., Shakirova, A.I. (2012). Evaluation of business and economic activity as a short-term forecasting tool. Herald of the Russian Academy of Sciences, 4, 290-294.

Fakhrutdinova, E., Kolesnikova, J., Yurieva, O., Kamasheva, A. The commercialization of intangible assets in the information society/l World Applied Sciences Journal. Volume 27, Issue 13, 2013, Pages 82-86.

Fakhrutdinova, E., Safina, L., Kolesnikova, J., Fedor, Mikhailov. Quality formation of working life of the youth// World Applied Sciences Journal. Volume 27, Issue 13, 2013, Pages 87-91.

Glebova I.S., Rodnyansky D., Sadyrtdinov R., Khabibrakhmanova R. and Yasnitskaya Y. Evaluation of Corporate Social Responsibility of Russian Companies Based on Nonfinancial Reportingll Middle-East Journal of Scientific Research 13 (Socio-Economic Sciences and Humanities): 143-148, 2013.

Fakhrutdinova, E., Safina, L., Shigapova, D., Yagudin, R. Legislative provision of the quality of working life in Russia// World Applied Sciences Journal.Volume 27, Issue 13, 2013, Pages 92-96.

Kirshin I.A., Datsyk A.A., Titov A.V. Forecasting the Dynamics of an Innovative Cycle. - World Applied Sciences Journal (Economics, Management and Finance). - 2013. - №27. - P. 197 - 201.

Glebova I.S., Sadyrtdinov R. and Rodnyansky D. Impact Analysis of Investment Attractiveness of the Republic of Tatarstan on Fixed Investments of its Leading Companies // World Applied Sciences Journal 26 (7): 911-916, 2013.

Glebova I.S., Khabibrakhmanova R. and Yasnitskaya Y. The Analysis of the Impact of the Investment Attractiveness Factors of the Region on the Fixed Capital Investments in the Economy of the Republic of Tatarstan II Middle-East Journal of Scientific Research 17 (10): 1498-1502, 2013. 
